\title{
CHALLENGES IN SPEAKING SKILLS OF STUDENTS AT B ENGLISH CENTER
}

\author{
NGA THI TUYET PHAN, THANH TRUC DANG \\ Industrial University of Ho Chi Minh City \\ ngaphan@iuh.edu.vn
}

\begin{abstract}
The purpose of this study was to explore challenges in English speaking skills encountered by a group of students at B English center. In this study, the reasons for difficulties in English speaking skills and the effects of these challenges on their speaking skills were investigated. This paper took the form of quantitative research with the use of a questionnaire. The statistical analyses showed that students at B English center had a number of challenges in English speaking skills, including pronunciation, listening, grammar and vocabulary. Moreover, findings suggest that they lacked confidence, maintained high anxiety or lacked opportunities for communicating in English outside the classroom. In addition, the results of the study reveal that these challenges affected negatively on their English performance and the target of learning the language as well as their motivation. Findings suggest that teachers may encourage students to overcome challenges in English speaking skills through the employment of interesting activities, which possibly provide students with more opportunities to practice English.
\end{abstract}

Key words: English speaking skills, quantitative, motivation

\section{INTRODUCTION}

These days, the English language plays a crucial role to weave the world into a single thread. English has the status of a second language in almost all countries where it is not the first language. Acquiring simple language for day to day communication is the main aim of learning any language (Ahmad,2016) [1]. Regarding learning a language, speaking is one of the most important skills to develop and enhance as means of effective communication. Speaking skills are regarded one of the most difficult aspects of language learning(Leong \&Ahmadi, 2017) [2]. However, many learners state that they have spent so many years studying English language but cannot speak it appropriately and understandably (Bueno, Madrid, \& Mclaren, 2006) [3]. As a result, speaking communication has so far become one of the problems faced by many foreign language learners. Moreover, some students do not know how to improve and overcome these challenges. Thus, one of the main purposes of the study reported here is to explore reasons for challenges in English speaking skills of a group of students at B English center. Besides, it is concerned with the effects of such challenges on students' communication abilities. Additionally, it was hoped that the findings would discover several ways of improving students' English speaking skills at B English center. The study addressed the following questions:

Q1. What are the challenges facing students' English speaking skills at B English center?

Q2. What causes these challenges?

Q3. How do these challenges affect student's English speaking skills?

\section{LITERATURE REVIEW}

\subsection{Communication}

According to Ahmad (2016) [1], communication is a sharing of feelings, ideas and opinions with others. Moreover, this can be intellectual, personnel spoken or written in nature. The researcher suggested that we live in groups and man is invariably a social animal. As the social needs insist, we share our thoughts with others. The two-way processes of communication motivate, inform, suggest, warn, order, change behavior and stably better relationships to make interaction meaningful and make oneself understood. Moreover, communication is a skill that contains systematic and continuous process of speaking and understanding [1].

It can be notified that communication is like a conversation with each other about daily life or the stories around us. Communication is something natural, something every day even, yet most of us have only value 
notion of the rules that govern it. Day in, day out, we ask questions, read, explain, write, listen, argue, discuss or hold our tongues (Mikael \& Roman, 2018) [4].

Furthermore, communication can further be defined as giving, receiving or exchanging information, facts, opinions or ideas by writing, speech or visual means, so that the message communicated is completely understood by recipients (Burns \& Joyce, 1997) [5].

\subsection{English speaking skills}

It claimed that speaking is a real language, which means that the capability to communicate in a language can be shown through the skill of speaking (Woodrow, 2006) [6]. One function of speaking is to communicate ideas in the situation where the other person is listening to words and can be in front of the speaker, looking at the gesture and facial expression. An act of communication through speaking is commonly performed in face to face interaction and occurs as a part of the dialogue or rather from the verbal exchange (Efrizal, 2012) [7]. Moreover, speaking is an interactive process of constructing meaning that involves producing, receiving and processing information (Lin, 2017) [8].

In addition, speaking is speech or utterances with the purpose of having the intention to be recognized by the speaker and the receiver. The receiver will process the statements in order to recognize the speaker's intentions (Burri, 2015) [9]. Besides, speaking is a highly complex interactive skill that has added the complexity of being very anxiety-provoking for learners of another language (Doff, 1998) [10]. Moreover, speaking means that the students repeat sentences or dialogues, or chant in English (Nguyen, 2011) [11].

According to Trinh (2019) [12], human communication is a complex process. Communication is used when they want to say something and transmit information. Speakers employ communication when they are going to inform someone something. Speakers apply language according to their own purposes. So, speakers should be both listeners and speakers at the same time for effective communication.

Moreover, it is important that speaking is the first mode in which children acquire language, it is part of daily involvement of most people with language activities, and it is the prime motor of language change. It provides our main data for understanding bilingualism and language contact. As language learners who had learned English intensively, the students should be able to interact orally with each other through English (Baker \&Westrup, 2003) [13]. Speaking is of great significance for people interaction because they use it everywhere and every day. Speaking is the way of communicating ideas and messages orally. If we want to encourage students to communicate in English, we should use the language in real communication and ask them to do the same process (Littlewood, 2007) [14].

\subsection{Challenges in English speaking skills}

Firstly, pronunciation is one of the most challenges in English speaking skills facing students who learn English as a foreign language. For example, Htwe (2017) [15] suggested that numerous evidence points out that pronunciation is a major problem in the communication process. She found out that the different dialects of Chinese command use of tones differentiate diverse words with first tones whereas the English language does not use tones to differentiate words from one another. Besides, pronunciation is a major problem especially among Chinese students taking their studies in the U.S. The researcher claimed that many languages do not use word stress, while word stress is key to understanding spoken English to communicate rapidly and accurately, even in difficult conditions. As such, the common pronunciation problems among Chinese students are often brought about by the dissimilar in structure between the two languages (Robby, 2010) [16].

Secondly, speaking skills cannot be developed unless we develop listening skills(Gan, 2012) [17]. Because students have to understand what speakers say or discuss. In fact, every speaker plays the role of both a listener and a speaker. Therefore, one is certainly unable to respond if he/she cannot understand what is said, which means speaking is closely related to listening (Kelly, 2013) [18]. However, according to Higgins (1995) [19], another problem in listening is the elision of a sound or exactly a syllable in a word. Thus, students cannot recognize the words that they hear. Once they try to comprehend every single word, there is little chance for them to discover the key words which give them clues to understand the listening text.

In addition, lacking ideas is one of the most challenges of English speaking skills. It is because speaking is one way to communicate with ideas and through a message orally [14]. Students struggle to think and 
express their ideas. It is very difficult for learners to respond when their teachers ask them to tell things in a foreign language because they have little opinions about what to say, which vocabulary to apply, or how to use grammar accurately (Tanveer, 2007) [20]. Students find it difficult to have a conversation on a topic that they know little about (He \& Chen, 2010) [21].

Furthermore, students are also unconfident and shy when speaking English. Any other factors such as nervousness and "afraid of making mistakes" result in failure to produce a correct form of English speech (Bashir, Azeem\&Dogar, 2011) [22]. Students are worried about making mistakes, fearful of criticism or losing face [18]. As a result, they feel more depressed in learning English. It asserts that a foreign language classroom to can create inhibitions and anxiety easily (Kurtus, 2001) [23]. Besides, their lack of selfconfidence in using the language is linked to their poor proficiency in various language skills, causing them to become afraid or embarrassed of making mistakes (Baldwin, 2011) [24]. Fear of mistakes becomes one of the main factors of students' reluctance to speak in English in the classroom (Baker, 2014) [25]. Therefore, students' lack of confidence usually occurs when students realize that their conversation partners have not understood them or when they do not understand other speakers.

Besides, challenges in English speaking skills are believed to relate to other components of the English language. English learners and some students with learning difficulties may respond orally with language conversation errors such as grammatical errors or partial meaning (Bygate, 1987) [26]. English learners and students with learning difficulties may not know many other words in the text that will be crucial for their full understanding of the topic [26].Students' speaking performance was not good because they did not master the three elements of speaking, namely, vocabulary, grammar and pronunciation (Clifford, 1987) [27]. Cambridge (2008) [28] explored obstacles to speaking skills confronted by English-majored students in Hong Kong University and found that the students in this context significantly encountered several problems leading to their limitation of fluent speaking performance such as lacking vocabulary and focusing much on grammar structures.

\subsection{The reasons for these challenges}

The reason why pronunciation is also known to cause challenges in English speaking has been attributed to the fact that most of these students lack neutral grounds to practice their English skills and to sharpen their pronunciation skills, as a result it becomes difficult to speak English efficiently in the future (Eckard \& Kearny, 1981) [30]. In addition to difficulties in producing sounds, the difficulty in seeing the differences between sounds is also another reason why learners might have problems with speaking (Flowerdew \& Miller, 1996) [31].

Besides, many factors cause listening challenges in speaking skills. The problems were believed to cause by speech rate, vocabulary and pronunciation (Florez, 1999) [32]. According to Florez, (1999) [32], these kinds of features may be encountered when the message is spoken at such a rapid speed that the sentences uttered cannot be spoken word by word. Moreover, once they try to comprehend every single word, there is little chance for them to discover the key words which give them clues to understand the listening text (Tuan \& Mai, 2015) [33]. Moreover, learners often concentrate on grammar and vocabulary test to past examinations and tests at school.

Another reason for speaking challenges is the employment of mother tongue in class. Tuan and Mai (2015) [33] listed some reasons why students use mother-tongue in class. It is easier for them to talk and share the information. According to Leong \& Ahmadi (2017) [2], the application of the mother-tongue is very natural for learners to use. If teachers do not urged their learners to talk in English, learners will automatically use their first language to explain something to their classmates.

Ur (1996) [36] also stated that the fear of speaking English is pertinent to some personality constructs like anxiety, inhibition, and risk taking. They emphasized that speaking a language sometimes results in anxiety. Sometimes, extreme anxiety may lead to despondence and a sense of failure in learners. According to Varasarin (2007) [37], the primary reason of fear of mistakes is that students are afraid of looking foolish in front of other people and they are concerned about how other will see them. Especially, speaking in front of people is one of the more common fears that students encounter and feeling of shyness makes their mind go blank or that they will forget what to say (Woodrow, 2006) [38]. 


\subsection{Impacts of challenges on students' speaking skill}

The difficulties of pronunciation affect students' ability to speak English effectively. Woodrow (2006) [6] investigated Chinese students in New York Universities and found that many Chinese students were stressful to learn English language and to polish its pronunciation, which demonstrated that pronunciation is a challenge that potentially affected the communication process. In particular, incorrect pronunciation of American English by Chinese college students from Columbia University and St. Johns University have been mostly blamed for interfering with optimal communication and success due to the wrong utterance of words that made the communication process ineffective. Moreover, Chinese students struggling to get the right pronunciations tended to shy away from participating in active school activities in fear of being looked down upon as well as fear of being misunderstood (Krashen, 1982) [39]. Thus, incorrect pronunciation is one of the most important factors that affect student's speaking English.

According to Krashen (1982) [39], a variety of effective variables has been confirmed to be related to success in second language acquisition in research over the last decade but most of those studies examined three categories: motivation, self-confidence and anxiety. Meanwhile, the term of anxiety is an instant, transitory emotion which can immediately impact on child cognition in specific condition and make them feeling worried and nervous, all of these events can extremely impact on memory and learning process (Beck, 1985) [40]. However, Littlewood (1984) [41] interpreted this issue and argued that anxiety has a negative influence on working memory performance. Gan (2012)[ 17]concerned this with lack of motivation in speaking English.

Besides, Thornbury (2005) [42] study explored obstacles to speaking skills confronted by English-majored students in Hong Kong University and found that the students in this context significantly encountered several problems leading to their limitation of fluent speaking performance such as lacking vocabulary, focusing much on grammar structures, having limited in-class speaking opportunities, and lacking English speaking environment. This lack of self-confidence also becomes a serious problem which affected the students' speaking performance. The author concluded that it was difficult for the students to master English speaking skills if they were not confident with their own speaking ability [14]. Language anxiety influenced learning and performance negatively [20]. Other authors also argued that anxiety causes negative effect on performance (Liu, 2007) [43].Because of the impact of language anxiety in learning to speak a foreign language (Indrianty, 2012) [44], it is certainly a problem if learners do not know what words to say. It is asserted that being pointed out to perform in English class emerges anxiety for learner, and it has negative effects on performance (Pennington, 2014) [45].

\section{METHODS}

\subsection{Participants}

To carry out this research, students at B English center were the participants of this study. The questionnaires were delivered to these participants. There were 40 participants, 17 males and 23 females completing a survey in my research. Students were at the ages from 13 to 15.

\subsection{Research instruments}

The research was conducted in the form of a quantitative study. In order to be able to use mathematically based on methods, the data have to be in numerical form (Muijs, 2011) [46]. Quantitative research is necessary in collecting the data to explain a particular phenomenon. Therefore, it can be easy to collect the information by using questionnaire. It is argued that particular questions seem immediately to be answered using quantitative methods [46]. There were three parts in the questionnaire, including English speaking challenges, the reasons and the effects of these challenges, as the data is ready to be available for us in numerical form. The researchers developed a questionnaire in which students helped to rate a number of statements (for example 'do you have pronouncing troubles when communicating in English?") as either 'yes', 'definitely yes', 'no', or ' definitely no'. Students could tick the answers of their choices. Quantitative research is good at providing information from a large number of units, but not when the writer wants to explore a problem or concept in depth.

There are 6 questions of part 1 with several answer options for students. The questions discussed their challenges in English speaking skills. Part 2 includes 4 questions investigating the reasons for communication challenges. This part targets the factors that may create communication challenges for 
students. The last part consists of 7 items investigating the effects of English speaking challenges. Participants were expected to identify the challenges that influenced their English speaking skills.

\section{FINDINGS}

\subsection{Speaking communication challenges}

Table 1: Speaking communication challenges

\begin{tabular}{|l|c|c|}
\hline \multicolumn{1}{|c|}{ Statements } & Yes & Definitely yes \\
\hline 1.Students' pronouncing troubles & $87.5 \%$ & $12.5 \%$ \\
\hline 2. Students' listening troubles & $60 \%$ & $40 \%$ \\
\hline 3. Students' grammatical troubles & $75 \%$ & $25 \%$ \\
\hline 4. Students' vocabulary problems & $73 \%$ & $27 \%$ \\
\hline 5. Expressing a complex idea/problem & $10 \%$ & $0 \%$ \\
\hline 6. Difficulties in giving a question & $67.5 \%$ & $32.5 \%$ \\
\hline
\end{tabular}

The table above showed that pronunciation problems were the most important problems facing the participants in English speaking skills with the highest percentage (accounted for 87.5\%). The figure pointed out that students met numerous pronunciation problems when communicating in English. Meanwhile, just $10 \%$ of the students could communicate a complex idea/problem effectively. The lowest rate illustrated that the participants obviously found it difficult in presenting a complex opinion or problem in English speaking process.

\subsection{The reasons for communication challenges}

Table 2: The reasons of these challenges

\begin{tabular}{|l|c|}
\hline \multicolumn{1}{|c|}{ Statements } & Percent \\
\hline The chances of communicating in English & $62.5 \%$ \\
\hline Students' confidence in English speaking & $2.5 \%$ \\
\hline The effects of bad listening skills & $100 \%$ \\
\hline The effects of narrow speaking skills & $100 \%$ \\
\hline
\end{tabular}

As seen in the table above, bad listening skills and narrow speaking skills accounted for the highest percentage, reaching $100 \%$ of the participants saying that was the most major reason for English speaking challenges. Meanwhile, just $2.5 \%$ of the students were confident in English speaking.

4.3 How do these challenges affect your English speaking skills?

Table 3: The effects of these challenges

\begin{tabular}{|l|c|}
\hline \multicolumn{1}{|c|}{ Statements } & Percent \\
\hline Find it difficult to communicate with English teacher & $90 \%$ \\
\hline Affect your speaking performance & $50 \%$ \\
\hline Become more passive when speaking English & $92.5 \%$ \\
\hline Feel unconfident by challenges in speaking skills & $95 \%$ \\
\hline Make in misunderstanding in the conversation & $90 \%$ \\
\hline Influence on target language communication & $45 \%$ \\
\hline Feel worried about lacking the vocabulary, grammatical and pronouncing mistakes & $100 \%$ \\
\hline
\end{tabular}


The figures showed that most of the students strongly agreed and agreed on all the items. Specifically, many students felt worried about lacking of vocabulary, grammatical and pronouncing mistakes with the highest proportion (accounted for 100\%). Besides, $95 \%$ of the participants thought that they were less confident by challenges in speaking skills.

\section{DISCUSSIONS}

\subsection{Research question 1: What are the challenges facing students at B English center in English speaking skills?}

In order to collect data for this question, 6 open-ended questions investigating English speaking challenges were used to find out overall students' challenges in English speaking skills. In general, the results collected from the students' questionnaires showed that many students at B English center faced the difficulties in English communication.

As it was shown from the analysis, there was clear indication that pronunciation was the most important challenge facing student participants. In general, the participants had the same problems which were an obstacle to pronounce correctly the words. Especially, students at B English center mostly found word-final and vowels challenging in English speaking. The findings supported the studies of other researchers. For example, according to Htwe (2017) [15], pronunciation was the main difficulty in the communication process. Moreover, the challenges were caused by the dialects of Chinese from Chinese students. Meanwhile, [16] also pointed out that pronunciation was also the most challenges among Chinese students taking their studies in the U.S. They preferred word stress to communicate rapidly and accurately.

These obtained results also demonstrated that just a few students could express a complex idea or problem. In addition, many students did not have enough vocabulary and information to communicate this idea or problem. Similarly, Tanveer (2007) [20] also stated that it was difficult for English learners to answer when their teachers asked them to tell things in a language since they had not enough opinions about what to say, which vocabulary to apply or how to use grammar accurately. Therefore, He and Chen (2010) [21] found it difficult for students to have a conversation on a topic that they knew little about.

\subsection{Research question 2: What are the reasons for these challenges?}

In order to have data for this section, 4 closed-ended questions were employed to know the reason for these challenges.

In term of listening, results showed that listening was the most significant reason related to English speaking challenges. Florez, (1999) [32] stated that the speech rate, vocabulary, and pronunciation caused to listening problems. However, it claimed that these kinds of features might be encountered when the message was spoken at such a rapid speed that the sentences uttered could not be spoken word by word [32]. Moreover, once they tried to comprehend every single word, there was little chance for them to discover the keywords which gave them clues to understand the listening text.

The statistics showed that a few students felt confident in communication, while the others faced an obstacle of lacking confidence in English speaking. In particular, the participants felt afraid of making mistakes. Some students felt that someone else noticed their mistakes. Thus, they felt shy when speaking in front of other people. The results of [34]'s study pointed out that student's feeling of stress, anxiety or nervousness may impede their language learning and performance abilities.

Moreover, [35] also pointed out that their low ability in speaking English was the main cause of students' confidence. In this case, as they add, many students thought that their English was not good and felt that they could not speak English well. In accordance with Ur (1996) [36]'s study results, the fear of speaking English was related to some personality constructs like anxiety, inhibition, and risk taking. According to Varasarin (2007) [37], students were afraid of looking ridiculous in front of other people and they were concerned about how others would see them. Especially, Woodrow (2006) [38] also said that speaking in front of people was one of the more common fears that students faced and feeling of shyness made their mind go blank or that they would forget what to say.

\subsection{Research question3: How do these challenges affect student's learning English speaking skills?}

In order to gather data for this question, 7 closed items were designed to find out the most common effects of challenges in English speaking skills. In general, these challenges affected students' English speaking process seriously. The results showed that a great number of participants strongly agreed or agreed with 
most of the items in section 3 of the questionnaire. It also revealed that students agreed with the given statements, which related to their influences of their communicating in English.

The results concerning EFL students' expectations of their teachers' orientation for more effective promotion of learners' English speaking skill can be summarized as follows:

- Find it difficult to communicate with English teacher

- Affect speaking performance

- Become more passive when speaking English

- Feel unconfident by challenges in speaking skills

- Make a misunderstanding in the conversation

- Influence on target language communication

- Feel worried about lacking the vocabulary, grammatical and pronouncing mistakes

The findings illustrated that most of students felt worried about lacking of vocabulary and grammatical and pronouncing mistakes. Contrarily, Woodrow (2006) [6] investigated to Chinese students in New York Universities that many Chinese students were stressful to learn English language and to polish on its pronunciation, such as to demonstrate that pronunciation is a challenge that potentially impacted the communication process negatively. It means that incorrect pronunciation is one of the most factors that affect student's speaking English negatively. However, most of those studies examined the three categories: motivation, self-confidence and anxiety. Therefore, Suherdi (2012)[41] argued that anxiety had a negative effect on working memory performance. Efrizal (2012) [7] linked this with lack of motivation in speaking English. Moreover, the findings of Littlewood (2007) [14] found that lack of self-confidence also became a serious problem which affected the students' performance unexpectedly. According to Indrianty (2012) [44] and Pennington (2014) [45], anxiety caused negative effects on performance.

In short, results of the current study show that students at B English center had many challenges in English speaking skill. It seems that there was a shortage of effective methods to improve their communicating in English. Future research investigating this issue is in need.

\section{CONCLUSION}

This paper investigated the challenges of the students in English speaking skills. It seems that the mentioned factors in this paper have an important role in developing learners' speaking skills. First of all, the factors made students less confident when they speak with their friends. Moreover, they drove the students to be shy in front of people. The findings of this paper indicated that learners with higher anxiety and low motivation have serious difficulties in speaking skills. The results showed that pronunciation problems, listening, even vocabulary and grammatical problems are the reasons for English speaking challenges. Thus, students could not speak easily and effectively. Moreover, they could not express complex ideas or problems fluently and even raise a question for partners. Based on the review of the literature in the study, the teacher should design activities to catch students' attention in order to improve the learners' selfconfidence and choose the best way to encourage them more.

Secondly, the results show that students had a few chances of practicing English communication. Thus, it is expected that students should have a friendly and international environment that can help them overcome their difficulties in English speaking. They should limit the usage of the mother tongue in learning English. Teachers may want to encourage students to spend much time to speak English by taking part in speaking activities.

Finally, the participants hope the teacher has an effective lesson that makes them motivated in learning English. The teacher should support students to overcome possible problems and remind them not to worry about making mistakes. In addition, giving instructions in how to correct learners' mistakes may lessen students' worries about making mistakes.

\section{REFERENCES}

[1]Ahmad, S. R. (2016). Importance of English communication skills. International Journal of Applied Researcher, PP. 478-480. Retrieved from 
www.allresearchjournal.com/archives $/$ year=2016\&vol=2\&issue $=3 \&$ part=H\&ArticleId=1684

[2] Leong, L., \&Ahmadi S. M. (2017). An Analysis of Factors Influencing Learners’ English Speaking Skill. Iran: University ofGuilan. Retrieved from http://ijreeonline.com/article-1-38en.html

[3] Bueno, A., Madrid, D., \& McLaren, N. (2006). TEFL in Secondary Education. Granada: Editorial Universidad de Granada.

[4] Mikael, K. (2018). The Decision Book: Fifty Models for Strategic Thinking (Fully Revised Edition). In K. Mikael, The Decision Book: Fifty Models for Strategic Thinking (Fully Revised Edition) (p. 55).

[5] Burns, A., \& Joyce, H. (1997). Focus on Speaking. Sydney: National Center for English Language Teaching and Research.

[6] Woodrow, L. (2006). Anxiety and Speaking English as a Second Language. RELC Journal, 37(3), 308-328.

[7] Efrizal, D. (2012). Improving Students' Speaking through Communicative Language Teaching Method at MtsJaalhaq, Sentot Ali Basa Islamic Boarding School of Bengkulu, Indonesia. International Journal of Humanities and Social Science, 2(20), 127-134.

[8] Lin, X.C. (2017). Pronunciation problems as a hindrance to effective communication among Chinese Students. Retrieved from http://www.nyu.edu/classes/keefer/waoe/linchengxu.pdf

[9] Burri, M. (2015).Student Teachers' Cognition about L2 Pronunciation. Instruction: A Case Study. Australian Journal of Teacher Education, 40(10), n10.

[10] Doff, A. (1998). Teach English: A training Course for Teacher. Cambridge University Press.

[11] Nguyen, T. H. (2011). Students Lack Confidence to Use English.

Retrieved from http://vietnamnews.vnagency.com.vn/TalkAround-town/212262/Students-lackconfidence-to-useEnglish. Html (July15, 2011)

[12] Trinh, V. H. (2019). Difficulties and strategies in listening comprehension. Retrieved from https://hu.edu.vn/139/662/Difficulties-And-Strategies-In-Listening-Comprehension-TrinhVinh-Hien.

[13] Baker, J., \&Westrup, H. (2003). Essential speaking skills: A handbook for English language teachers. London: Continuum.

[14] Littlewood, W. (2007). Communicative Language Teaching. Cambridge: Cambridge University Press.

[15] Htwe, Y. (2007). Shyness Main Obstacle to Learning English. Retrieved from: http/no371/n010.htm (March 15, 2011)

[16] Robby, S. (2010). Conquer Your Fear of Making Mistakes when Speaking English.

Retrieved from: http://englishharmony.com/conquer-fear-of-making-mistakes-when-speaking-English/ (March 15. 2011)

[17] Gan, Z. (2012). Understanding L2 Speaking Problems: Implications for ESL Curriculum Development in Teacher Training Institution in Hong Kong. Australian Journal of Teacher Education. 37(1): 43-59.

[18] Kelly, L. G. (2013). 25 centuries of language teaching. Rowley, MA: Newbury House

[19] Higgins, J. M. D. (1995). Facilitating listening in second language classrooms through the manipulation of temporal variables. Unpublished doctoral thesis, University of Kent at Canterbury.

[20] Tanveer, M. (2007). Investigation of the Factors That Cause Language Anxiety for ESL/EFL Learners [21] He, S. X., \& Chen, A. J. Y. (2010). How to Improve Spoken English. 
Retrieved from http://sites.google.com/site/languagejournal/Home/how-to-improve-spoken-English (February 19, 2010)

[22] Bashir, M., Azeem, M., \&Dogar, A. H. (2011). Factor Effecting Students' English Speaking Skills. British Journal of Arts and Social Sciences, 2(1), 34-50.

[23] Kurtus, R. (2001). Overcome the Fear of Speaking to Group. Retrieved from http://www.schoolforchampions.com/speaking/fear.htm (June 20, 2010)

[24] Baldwin, C. (2011). How to Overcome Shyness during an Oral Presentation.

Retrieved from http://www.ehow.com/how_7852354_overcome-shyness-during-oralpresentation.html (February17, 2011)

[25] Baker, A. (2014). Exploring teachers' knowledge of second language pronunciation techniques: Teacher cognitions, observed classroom practices, and student perceptions. Tesol Quarterly 48.1: 136-163.

[26] Bygate, M. (1987). Speaking. Oxford: Oxford University Press.

[27] Clifford, R. T. (1987). Language Teaching in the Federal Government: A Personal Perspective. Annals, AAPSS, 490.

[28] Cambridge Advanced Learner's Dictionary. (2008). Cambridge Advanced Learner's Dictionary, $3^{\text {rd }}$ Ed. Cambridge: Cambridge University Press.

[29] Doff, A. (1998). Teach English: A training Course for Teacher. Cambridge University Press

[30] Eckard, R., \& Kearny, M. (1981). Teaching Conversational Skills in ESL. Washington: Center of Applied Linguistics.

[31] Flowerdew, J., \& Miller, L. (1996). Student perceptions, problems and strategies in second language lecture comprehension RELC Journal 23 (2), 60-80.

[32] Florez, M. A. (1999). Improving Adult English Language Learners' Speaking Skills. ERIC Digest. (ERIC Document Reproduction Service No. ED: 435204)

[33] Tuan, N. H., \& Mai, T. N. (2015). Factors Affecting Students' Speaking Performance at Le Thanh Hien High School. Asian Journal of Educational Research, 3(2), 8-23.

[34] Torky, S. A. E. F. (2006). The Effectiveness of a Task-Based Instruction Program in Developing the English Language Speaking Skills of Secondary Stage Students.Ph.D.Dissertation.Curricula and Methods of Teaching.Department, Women's College, Ain Shams University.

[35] Tahir, S. Z. (2013). Teaching speaking (English) through yahoo messenger: Theory and Practice. In S. Z. Tahir, Teaching speaking (English) through yahoo messenger: Theory and Practice (p. 55). Jakarta: Media PustakaQalam.

[36] Ur, P. (1996). A course in Language Teaching. Practice and Theory. Cambridge: Cambridge University Press.

[37] Varasarin, P. (2007). An action research study of pronunciation training, language learning strategies and speaking confidence. Ph.D. dissertation, Victoria University, Thailand.

[38] Littlewood, W.(1984). Foreign and second language learning. Cambridge: Cambridge University Press.

[39] Krashen, S. D. (1982). Principles and Practice in Second Language Acquisition. New York: Pergamon Press.

[40] Beck, E. (1985). Anxiety Disorders and Phobias: A Cognitive Perspective, Basic Books, New York.

[41] Suherdi, D. (2012). RekonstruksiPendidikanBahasa: SebuahKeniscayaanbagiKeunggulanBangsa. Bandung: CELTICS Press. 
[42] Thornbury, S. (2005). How to Teach Speaking. England: Pearson Educational Limited

[43] Liu, M. (2007). Anxiety in Oral English Classrooms: A Case Study in China. Indonesian Journal of English Language Teaching. 3 (1), pp.119-137.

[44] Indrianty, S. (2012). Students' Anxiety in Speaking English: A Case Study in Hospitality and Tourism College in Bandung. (Thesis, Universitas Pendidikan Indonesia, 2012, Tidakditerbitkan).

[45] Pennington, M. (2014). Phonology in English language teaching: An international approach. Routledge.

[46] Muijs, D. (2011). Doing Quantitative Research in Education with SPSS. In D. Muijs, Doing Quantitative Research in Education with SPSS (p. 35). London: Sage Publications Ltd

\section{NHŨ̉NG THÁCH THỨC TRONG KỸ NĂNG NÓI CỦA HỌC VIÊN TẠI TRUNG TÂMM ANH NGỬ B}

Tóm tắt: Mục tiêu của nghiên cứu này nhằm khám phá những thách thức trong kỹ năng nói tiếng Anh mà một nhóm học viên tại trung tâm Anh ngữ $\mathrm{B}$ gặp phải. Nghiên cứu tìm hiểu những lý do gây ra những khó khăn này và ảnh hưởng của chúng lên kỹ năng nói của các học viên. Nghiên cứu sử dựng phương pháp định lượng và bảng câu hỏi. Số liệu nghiên cứu cho thấy nhóm học viên gặp phải một số thách thức, bao gồm phát âm, nghe, ngữ pháp và từ vựng. Kết quả nghiên cứu cho thấy rằng, các học viên thiếu tự tin, thường lo lắng và thiếu các cơ hội giao tiếp tiếng Anh ngoài lớp học. Thêm vào đó, những thách thức này ảnh hưởng tiêu cực đến khả năng sử dụng tiếng Anh, đến mục đích và động cơ học tập của họ. Nghiên cứu khuyển nghị người dạy sử dụng các hoạt động học thú vị, cung cấp nhiều cơ hội để người học rèn luyện kỹ năng nói nhằm giúp đỡ, khuyến khích học viên vượt qua những thách thức này.

Từ khóa: kỹ năng nói tiếng Anh, định tính, động lực học

Ngày nhận bài: 12/09/2019

Ngày chấp nhận đăng: 17/02/2020 